spin of a proton is not unity, fission energies are not measured in millielectron volts, $\mathrm{U}^{234}$ is not of significance, the scattering length of hydrogen is not $-0.30 \times 10^{-14} \mathrm{~m}$ and bond lengths of 'several hundreds of ångströms' are surprising.

\section{Department of Physics}

The University of Sheffield

Sheffield 10

England

\section{Acta Cryst. (1979). A35, 510}

Structures in nature as a strategy for design. By $P$. Pearce. Pp. xvii +245 . Cambridge, Mass: MIT Press, 1978. Price $£ 31 \cdot 50$.

The author has produced an illustrated manual of geometry with useful descriptions of many varieties of polyhedra and their ordered combinations into finite and infinite assemblies. Polyhedra are addictive, and people hooked on them tend to loose all sense of proportion (also in the architectural sense). This is a pattern-book for such addicts.

Crystallographers will indeed find this thesaurus of absorbing interest. The least familiar but most important section deals with structures composed of membranes or minimal surfaces slung over space frames. Most of the matter has been published elsewhere but the collection is nevertheless useful, although many of the illustrations and descriptions are very hard to understand. However, crystallographers will be better placed than others and should derive useful insights into complex spatial structures. The geometry seems mostly sound but the engineering is vestigial and the architecture naive - who wants to live in a house designed like a polyhedral virus? If we have no forces but the forces between atoms, why should the geometry of atomic structures be scaled up when the forces cannot be scaled up?

Unaccountably, the bibliography (which is worthwhile) only goes up to about 1970 , since when much of relevance has appeared, for instance, in the Journal of Ultrastructure Research and the Journal of Molecular Biology.

A. L. MACKAY

Department of Crystallography

Birkbeck College

Malet street

London WC1E $7 A X$

\section{Acta Cryst. (1979). A35, 510}

Рентгеноструктурный анализ библиографический указатель литературы за 1960-1975 гг. М. М. УМАНСКИЙ. (X-ray Structure Analysis: a Bibliography, 1960-1975. By M. M. UManskiJ. Pp. 174. Leningrad: Leningrad Scientific Publishing Co., 'Burevestnik', 1978.) Price, 1 rouble 13 kopec.

This little book is a fairly comprehensive bibliography of textbooks and articles on X-ray crystallography over the past two decades or so.

Although addressed to readers of Russian, it would undoubtedly have real value, for reference purposes, for any
English-reading scientist, since over half of all the entries are, in fact, in English.

The book is in two parts. Part I (34 pp., 174 entries) lists books; part II (140 pp., 1350 entries) lists scientific papers. The booklist is itself divided into two sections: textbooks proper (121 books) and reference books or tables (53 entries); but, in contrast to the subject-subdivision of the papers (see below) the books are not collected into subject areas at all, presumably because the selection has been rather narrowly limited to explicitly crystallographic titles. The scientific papers are divided up into sections according to their subject matter. In each of these sections ( 22 in all) the ordering of the entries is the same: first, all the Russianlanguage titles are given, in Russian script, the listing being in chronological order, starting from the earliest, usually a little earlier than 1960, and finishing at about 1975; then all the non-Russian entries (almost all are in English) are given in Latin script, again in chronological order from about 1960 to late 1975. The topics into which these papers are divided include, for example, Monochromatization; Diffractometers (this is the largest section: 166 entries); Indexing of photographs; Precision measurement of lattice parameters; Investigation of texture; and so on. The largest single topic is, Theory and methods of structure determination: this embraces five sections, totalling 265 papers.

Part 1 , which is the list of book titles, has an interesting feature. This is the inclusion, in many cases, of a short paragraph of commentary (in Russian) below particular book titles. Also, any multi-author collection has all of its section titles and their authors listed in full (in English). These commentaries must be quite useful for the Russian language readers for whom this book is intended.

The standard of production of this book is not very good, with variable quality of print, and not-infrequent typographical errors; but it is inexpensive. As for the matter of the cut-off date, about the end of 1975, Professor Umanskij is currently hoping that a Supplement covering the period 1976-1978 will be produced before the end of 1979 .
School of Chemistry
University of Leeds
Leeds LS $29 \mathrm{JT}$
England

J. H. ROBERTSON

Acta Cryst. (1979). A35, 510

\section{Books Received}

The following books have been received by the Editor. Brief and generally uncritical notices are given of works of marginal crystallographic interest; occasionally a book of fundamental interest is included under this heading because of difficulty in finding a suitable reviewer without great delay.

An introductory guide to information sources in physics. By L. R. A. Melton. Pp. ii + 44. London and Bristol: The Institute of Physics, 1978. Price $£ 1.25$ (or 90p per copy for 10 copies or more). This is a booklet of advice for students on how to use library facilities.

Semi-metals \& narrow-bandgap semiconductors. By D. R. LovetT. Pp. viii +256 , Figs. 149, Tables 26. London: Pion Limited, 1977. Price $£ 8 \cdot 50$, US $\$ 17.50$. A review of this book, by T. Okada, has been published in the April issue of Journal of Applied Crystallography, page 262. 